\author{
B. Grigorov, N. Velev, A. Assenov, M. Nazarov, M. Gramatikov, B. Genova \\ \& K. Vassilev
}

\title{
Grassland habitats on the territory of Dragoman Municipality (Western Bulgaria)
}

\begin{abstract}
Grigorov, B., Velev, N., Assenov, A., Nazarov, M., Gramatikov, M., B. Genova, B. \& Vassilev, K.: Grassland habitats on the territory of Dragoman Municipality (Western Bulgaria). - Fl. Medit. 31: 89-100. 2021. - ISSN: 1120-4052 printed, 2240-4538 online.

This study aims at mapping and investigating the grassland habitats, defined by Directive 92/43/EEC, on the territory of Dragoman Municipality, Bulgaria. The municipality is located in the western part of the country and is characterized by semi-mountainous terrains and temperate climate. During the fieldwork in 2019 and 2020, 212 relevés were collected, following the Braun-Blanquet approach. Additionally, grassland habitats were checked up at 1340 field points. Grassland habitats covered $89.57 \mathrm{~km}^{2}$ or $27.6 \%$ of the whole municipality's territory. Six grassland habitat types were differentiated: *Rupicolous calcareous or basophilic grasslands of the Alysso-Sedion albi (6110), Semi-natural dry grasslands and scrubland facies on calcareous substrates (Festuco-Brometalia) (*important orchid sites) (6210), Eastern subMediterranean dry grasslands (62A0), Molinia meadows on calcareous, peaty or clayey-siltladen soils (Molinion caeruleae) (6410), Hydrophilous tall herb fringe communities of plains and the montane to alpine levels (6430) and Lowland hay meadows (6510). The most widespread were the xeric grasslands presented within habitats 6210 and 62A0. Traditionally, they are managed as pastures. Habitat 6210 is found on silicate and calcareous substrates, whereas habitat $62 \mathrm{~A} 0$ is limited to calcareous substrates only. Mesic grasslands were presented by habitat 6510. It is distributed mainly in the Dragoman lowlands and along rivers. Habitats 6410 and 6430 are locally found and cover $0.07 \mathrm{~km}^{2}$ and $0.001 \mathrm{~km}^{2}$, respectively. The condition, structure and threats for each habitat type are taken into consideration also.
\end{abstract}

Key words: mapping, natural conservation, NATURA 2000 network.

\section{Introduction}

Semi-natural grasslands can be considered among the most species rich habitats particularly in Europe (Wilson \& al. 2012; Roleček \& al. 2014; Turtureanu \& al. 2014; Dengler $\&$ al. 2016). A good basis for preserving this natural treasure and setting proper habitat conservation objectives is the adoption of Council Directive 92/42/EEC, due to its promotion of biodiversity protection (Council Directive 92/43/EEC). In this regard, habitat pro- 
tection is also an important issue, as Fahring (2003) pointed at in his study on the effects of habitat fragmentation.

Republic of Bulgaria, as being a part of the European Union, follows the EU legislation. The ecological network NATURA 2000 is being developed in Bulgaria since 2002. Nowadays, it includes 234 sites declared under the Habitat Directive and covers ca. 30.3\% of the country's territory. Habitat studies in Bulgaria are still being carried out by the minute and the vegetation investigations are at the very basis of them.

Some $40 \%$ of the territory of Dragoman municipality falls within two Sites of Community Interest: Dragoman (BG0000322) and Western Balkan Range and Forebalkan (BG0001040). Studies on vegetation and habitats in the municipality are still fragmentary and lack completeness. Grassland vegetation on the municipality's territory has been investigated partly by Velev \& al. (2011a, 2011b), Vassilev (2012) and Vassilev \& al. (2012). It is classified within Molinio-Arrhenatheretea and Festuco-Brometea classes. Wetland vegetation of the Dragoman Marsh has been studied by Apostolova \& al. (2001), Traykov \& Tosheva (2015) and Vassilev \& al. (2019). Grassland management regimes are reflected in the study of Velev \& Vassilev (2014). The condition of grassland ecosystems outside the NATURA 2000 network is assessed in the work of Sopotlieva \& al. (2018).

Western Bulgarian Mountains are characterized by highly diversified grasslands containing many rare and endemic species (Horvat \& al. 1974; Knapp 1979). At the same time, the semi-mountainous character of the territory combined with its ecological diversity define it as an interesting item for investigating. Furthermore, especially the local flora is rich in endemic and rare species such as Edraianthus serbicus Petrovič, Jurinea tzar-ferdinandii Davidov, Astragalus wilmottianus Stoj, Tulipa urumoffii Hayek, Salix rosmarinifolia L., etc (Vassilev 2012). The scientific interest in the investigation and mapping of grassland habitats in Dragoman Municipality is related to its proximity to the capital city of Sofia. The latter fact inevitably leads to an intensive anthropogenic impact on habitats and vegetation and especially to plant species and habitat loss. Intensively managed grasslands are mainly found around settlements and are typically ruderalized by overexploitation, while less accessible ones often are subjected to abandonment (Nikolov 2010; Vassilev \& al. 2011; Velev \& Vassilev 2014). Nowadays many abandoned pastures are to be observed all across the country. Abandonment affects biodiversity, ecology and syntaxonomy of grasslands (Velev \& Apostolova 2008; Meshinev \& al. 2009; Házi \& al. 2011; Vassilev \& al. 2011).

The investigation of habitats at a national level is a dynamic process and the current study is intended to contribute to this knowledge. Likewise, grassland habitats within the municipality's area are not completely investigated so far. The main effort is focused on investigating of distribution and condition of grassland habitats, as defined by Habitat Directive, on the whole territory of Dragoman municipality. It is also trying to refine some issues regarding NATURA 2000 habitat mapping like the territorial extent of some habitat polygons and species misinterpretation.

The aim of this study is a complete investigation and mapping of grassland habitats according to Directive 92/43/EEC on the territory of Dragoman Municipality. 


\section{Materials and Methods}

Geographical position of the study area - Dragoman Municipality is located in the western part of the country, it covers about $324 \mathrm{~km}^{2}$ and is characterized by a prevalent semi-mountainous relief. It includes the mountains of Chepun, Mala Planina and Viskyar, as well as the valleys of Sofia and Burel. The highest peak within the municipality's territory is Petrovski Krust (1205 m) in Chepun Mt.

Lythology - The area is underlain by carbonate and non-carbonate sediments and magmatic rocks, represented mainly by the following rock types: limestones, dolomites, sandstones, siltstones, marls and hornblende andesites, trachyandesites, andesitobasalts in extrusive, explosive and subvolcanic facies. Sedimentary rocks are accounting for more than $80 \%$ of the area, while magmatics are covering less than $10 \%$.

Soils - Soil types include predominantly rendzinas, leached and podzolized cinnamonic forest soils. The first soil type is typical for the northern and eastern parts of the investigated territory, while the other soil types are characterized by a mosaic distribution in the other parts of the area.

Climate and hydrology of the area - According to the climatic zoning of Bulgaria, Dragoman municipality falls in the Temperate climate zone. It is characterized by warm summers and cold winters (Velev 2010). The climate can also be identified as humid throughout the most parts of Dragoman Municipality with the exception of the southwestern section where the climate is moist subhumid. The main river arteries are Nishava and Gaberska. Other important rivers are Ezhovitsa, Letnishka, Shiroki dol, Kalugeritsa and Skakavets to the north and Kambelevska, Chekinska, Dervent and Sharabanitsa to the south. An important note is that the eastern section of Dragoman Municipality lacks surface runoff due to the karst rocks that are presented there, leading to a prevalence of the underground outflow where the waters emerge in the southern slopes of Mala Planina. The water richness is also accompanied by the presence of the Dragoman Marsh, located in the central part of the municipality. The marsh itself represents a karst water body and an important wetland zone in Bulgaria.

Fieldwork and mapping of habitats

The habitat and vegetation samplings were conducted in 2019 and 2020 field working seasons following Braun-Blanquet approach (1965). All relevés were plotted in homogenous areas of grassland communities and were assigned to a habitat type according to Directive 92/43/EEC. The whole territory was studied thoroughly and during the field trips 1340 field verification points were collected, which were taken from any representative part of the mapped polygons and are categorized to any habitat type (Fig. 1). The acquired data was applied in order to build the habitat map of the area.

The nomenclature of vascular plants followed Delipavlov and Cheshmedzhiev (2003), whereas the high rank syntaxa were harmonized with Mucina \& al. (2016).

The habitat types' determination was accomplished according to the Interpretation Manual of European Union Habitats (2013) and Kavrakova \& al. (2009) The application of the ArcGIS 10.1 software helped for the cartographic analysis. Spatial data from Forestry Management Plans and habitat mapping of NATURA 2000 in Bulgaria were also used. Habitat types were determined according to Directive 92/43/EEC (Interpretation Manual of European Union Habitats 2007; Kavrakova \& al. 2009). 'Habitat directive 


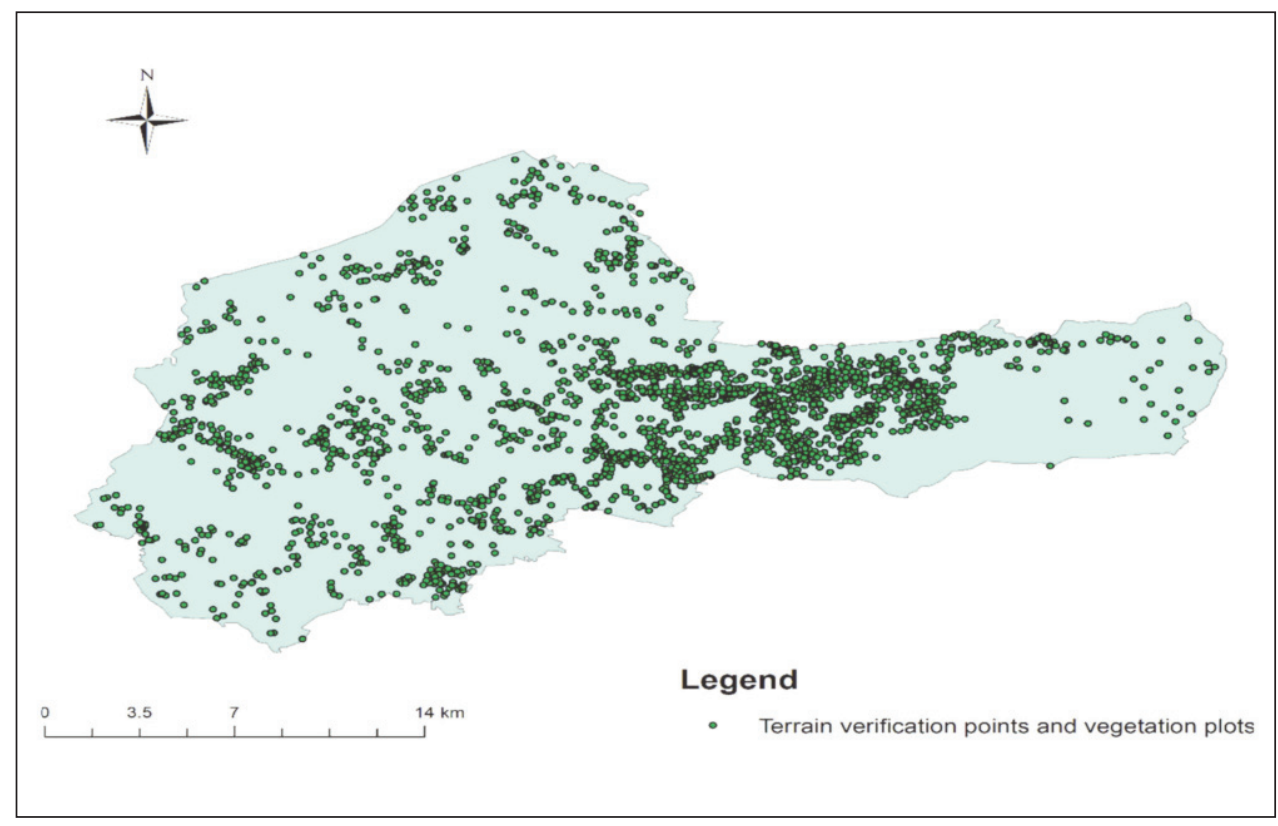

Fig. 1. Vegetation plots and validation points in Dragoman Municipality.

code' is abbreviated as 'HDC' throughout the text below. Mapping was done using ArcGIS 10.1 software (ESRI 2011). Spatial data was collected in the field using the GPS devise Juno BS by Trimble and was later laid over the most recent orthophoto images available. The habitat map was created by the application of the "Intersect" tool by combining the layers, containing forestry data from Forestry Management Plans, as well as data about agricultural areas and habitat data from the habitat mapping of NATURA 2000 in Bulgaria. Later, the "Cut polygon" tool was used in order to modify polygon area. Polygons were outlined manually by using features collected in the field as well as the orthophoto images. Mapping was done in scale 1:5000.

\section{Results \& Discussion}

\section{Habitat diversity}

They cover $89.57 \mathrm{~km}^{2}$ or $27.6 \%$ of the whole territory of Dragoman municipality (Fig. 2). Six habitat types were identified, as following: *Rupicolous calcareous or basophilic grasslands of the Alysso-Sedion albi (6110), Semi-natural dry grasslands and scrubland facies on calcareous substrates (Festuco-Brometalia) (*important orchid sites) (6210), Eastern sub-mediteranean dry grasslands (62A0), Molinia meadows on calcareous, peaty or clayey-siltladen soils (Molinion caeruleae) (6410), Hydrophilous tall herb fringe communities of plains and the montane to alpine levels (6430), and Lowland hay meadows (6510). 


\section{0 *Rupicolous calcareous or basophilic grasslands of the Alysso-Sedion albi}

Abiotic characteristic: This habitat can be found as a part of a mosaic (7 mosaic polygons) with habitat types 40A0 and 62A0 within the territory of Dragoman Municipality between 600 and $1000 \mathrm{~m}$ a.s.l. Terrains are flat or with a slope inclination up to $60-70^{\circ}$. These mosaics are located in the eastern part of the area, to the northwest and southeast of the villages of Golemo Malovo, Malo Malovo and Vasilovtsi. They cover a total area of $0.15 \mathrm{~km}^{2}$. The bedrock types are limestones and dolomites. Intensive heating occurs during the summer and the season also leads to prolonged droughts.

Vegetation structure: Very species-poor phytocoenosis with open horizontal structure with total cover $35-60 \%$. Cover of lichens and bryophytes is up to $10 \%$. Herb layer is formed by Achillea ageratifolia (Sm.) Boiss. Sedum album L., S. hispanicum L., Alyssum minus (L.) Rothm., Saxifraga tridactylites L., Arenaria serpylifolia L., Minuartia hybrida (Vill.) Schischk., Globularia aphyllantes Crantz, Poa badensis Willd., Hyacenthella leucophaea (K.Koch) Schur., Draba lasiocarpa Rochel., Sempervivum marmoreum Griseb., Jovibarba heuffelii Schott., etc. In the species composition are also found some endemic plants such as Edraianthus serbicus Astragalus wilmottianus. The most frequent lichens and mosses are Cladonia furfuracea Vain., Ceratodon purpureus (Hedw.) Brid., Syntrichia ruralis (Hedw.) F. Weber \& D. Mohr., Ditrichium flexicaule (Schwägr.) Hampe. Shrubland species, such as Corothamnus procumbens (Willd.) C. Presl and Syringa vulgaris L. also occur in the territory.

From syntaxonomical point of view this vegetation is transitional between classes Festuco-Brometea (all. Saturejion montanae) and Sedo-Scleranthetea (all. Alysso alyssoidis-Sedion).

\section{Semi-natural dry grasslands and scrubland facies on calcareous substrates (Festuco-Brometalia) (*important orchid sites)}

Abiotic characteristic: The habitat is widespread, accounting for an area of $53.53 \mathrm{~km}^{2}$ and is presented by 2033 polygons. It is equally distributed in range 600 to $1000 \mathrm{~m}$ a.s.1. Stands cover slopes with different exposition with rough microreleif. Terrains are flat or slightly inclined (up to $20^{\circ}$ ). Soils are shallow to moderately deep. The bedrock types are consisting mainly of limestones, dolomites and sandstones. It is used mainly for haymaking and as pastures.

Vegetation structure: Species-rich phytocoenoses with semi-open to closed horizontal structure and a projected coverage $85-100 \%$. The coverage of mosses and lichens is 5$15 \%$. Plant communities are rich in species with a prevalence of tussock-forming grasses, such as Chrysopogon gryllus (L.) Trin., Festuca dalmatica (Hack.) K. Richt., F. pseudodalmatica Krajina, F. valesiaca Gaudin., Dichantium ischaemum (L.) Roberty, Stipa capillata L., Poa angustifolia L. This habitat includes communities of alliances Festucion valesiacae, Chrysopogono-Danthionion and Brachypodion pinnati which are investigated in region by Vassilev (2012) and Vassilev \& al. (2012). Xero-mesophilic communities of the alliance Chrysopogono-Danthonion that are typical for deep, humid soils and on western and northern slopes have a transitional species compound with communities of the alliance Cynosurion cristati of Molinio-Arrhenatheretea class. Many xero-mesophilic species are common such as Briza media L., Agrostis capillaris L., Cynosurus cristatus L., Betonica officinalis L., Filipendula vulgaris Moench., Trifolium repens L., T. montanum L., 
Leucanthemum vulgare Lam. Communities of the alliance Brachypodion pinnati occur on limestone bedrock and are rich in calciphilous species, such as Brachypodium pinnatum (L.) P. Beauv, Anthyllis vulneraria L., Polygala major Jacq., Trifolium alpestre L., T.ochroleucon Huds. These vegetation types are used for haymaking and as pastures. Xerophilic communities are classified in the alliance Festucion valesiacae. Species with higher cover and abundance are Festuca dalmatica (Hack.) K.Richt., F. valesiaca Gaudin., Dichantium ischaemum (L.) Roberty, Chrysopogon gryllus (L.) Trin., Stipa capillata L. , Poa angustifolia L., Dorycnium herbaceum Vill., Medicago falcata L., Coronilla varia L.

\section{A0 Eastern sub-Mediteranean dry grasslands}

Abiotic characteristic: The habitat type is presented by 303 polygons and covers 31.88 $\mathrm{km}^{2}$. Stands are found predominantly on eastern and southern facing-slopes of Chepun Mt., Viskyar Mt. and Mala Planina Mt. within the range of 600-1000 m a.s.l. Terrains are flat to moderately inclined up to $45-50^{\circ}$. The bedrock type is of carbonate and dolomite rocks. Soils are shallow to deep, dry with rough microreleif and calcareous outcrops. The habitat type is sometimes used as a pasture land.

Vegetation structure: Communities have semi-open to closed horizontal structure with a projective coverage between $65-95 \%$. Mosses and lichens cover 10-35\%. In the species composition subdominants are Stipa eriocaulis Borbás, Festuca dalmatica (Hack.) K. Richt., Dichantium ischaemum (L.) Roberty, Artemisia alba Turra, Satureja montana subsp. kitaibelii Wierzb. ex Heuff., Potentilla cinerea Vill. Some polygons have a more heterogeneous structure and they lack a dominant species. Species composition is rich of calcareous species such as Euphorbia niciciana Borbás, Agropyron cristatum (L.) Gaertn., Melica ciliata L., Carex humilis Leyss., Teucrium montanum L., T. polium L., Sideritis montana L., Asperula purpurea (L.) Ehrend., Anthyllis vulneraria L., A. montana L., Leontodon crispus Vill. It is also rich of species with a conservation importance such as Himantoglossum jankae Somlyay, Kreutz \& Óvári, Hypericum rumeliacum Boiss., Astragalus wilmottianus, Achillea clypeolata Sibth., Jurinea tsar-ferdinandii, Tulipa urumoffii, Tragopogon balcanicus Velen., Edraianthus serbicus, Chamaecytisus jankae (Velen.) Rothm, etc. From syntaxonomical point of view this vegetation belongs to alliance Saturejon montanae of class Festuco-Brometea. Syntaxonomical diversity of this alliance on the territory of municipality is investigated by Vassilev (2012) and Vassilev \& al. (2012).

Together with habitat types 40A0, 6110 and 6210 it is also forming 1 mosaic polygon, which covers an area of $1.74 \mathrm{~km}^{2}$.

\section{Molinia meadows on calcareous, peaty or clayey-siltladen soils (Molinion caeruleae)}

Abiotic characteristic: This habitat type is restricted only to the most eastern part of the municipality at $800 \mathrm{~m}$ a.s.1. where it covers ca. $0.07 \mathrm{~km}^{2}$. It is located to the southeast of Tsraklevtsi village. Frequently, this habitat type is in mosaic with habitat 6510 Lowland hay meadows, so they form complex vegetation. Most of this complex habitat is to be found eastwards from the eastern municipality border and falls within the SCI BG0000322 Dragoman as part of the NATURA 2000 network. The bedrock types are mainly of carbonate origin. The soils in this area are thick and clayey with a slightly acid reaction. The habi- 
tat is characterized with a variable soil moisture throughout the year. Traditionally, in springtime the soils are flooded, but they can dry out for a long period in the summer.

Vegetation structure: Species rich mesic to hygrophilous grasslands with closed horizontal structure and total cover $80-95 \%$. Most frequent species are Molinia caerulea (L.) Moench, Danthonia alpina Vest., Agrostis capillaris L., Serratula tinctoria L., Sanguisorba officinalis L., Potentilla erecta (L.) Raeusch., Galium verum L., Lotus corniculatus L., Gentiana pneumonanthe L., Hieracium umbellatum L., Sieglingia decumbens (L.) Bernh., Bistorta major S. F. Gray., Iris sibirica L., Ranunculus polyanthemos L., Festuca pratensis Huds., Anthoxanthum odoratum L. Some tree species as Betula pendula Roth and Pyrus pyraster Burgsdorf are present also in the area by single individuals. The species composition of this habitat is characteristic with the presence of a very rare species in Bulgaria Salix rosmarinifolia. It is evaluated as Critically Endangered at national level (Apostolova \& Tsoneva 2009) and is included in the Red Data Book of the Republic of Bulgaria (Apostolova \& Tsoneva 2015). Salix rosmarinifolia is a shrub reaching up to $0.60-1.0 \mathrm{~m}$ in height. The whole population of $S$. rosmarinifolia L. occupies about 100 ha, but only a small part of it falls within Dragoman Municipality. The main part of the species' population is included into the BG0000322 Dragoman protected area. The vegetation is managed as haymaking grasslands and is regularly cut every year. Sometimes cattle are released freely to pasture after cutting. This vegetation belongs to alliance Molinion caeruleae W. Koch 1926, order Molinietalia caeruleae W. Koch 1926 and class Molinio-Arrhenatheretea Tüxen 1937. The phytocoenoses with $S$. rosmarinifolia L. are classified as association Junco effusiMolinietum caeruleae Tüxen 1954 (Hájek \& al. 2006).

\section{Hydrophilous tall herb fringe communities of plains and the montane to alpine levels}

Abiotic characteristic: This habitat has a limited distribution in the north of Kambelevtsi village at about 610-640 a.s.l and is covering only $0,001 \mathrm{~km}^{2}$. It occurs in a floodplain area on rather wet and nutrient-rich soils. Typically, ground water usually decreases in dry periods in summer, but soils never dry out completely. It is located over volcanic rocks.

Vegetation structure: Species-poor communities dominated by broad-leaved tall forb Filipendula ulmaria (L.) Maxim., which cover $80-90 \%$. The height of herbs is about 1-1.5 $\mathrm{m}$. In the species composition are also found some hygrophyte (e.g. Carex acutiformis Ehrh., Lythrum salicaria L., Epilobium hirsutum L., Mentha longifolia (L.) Huds.) and mesic (e.g. Festuca pratensis Huds., Agrostis stolonifera L., Deschampsia caespitosa (L.) Beauv.) species but their cover is up to $2-3 \%$. The maximum of vegetation development is in second half of summer period. The strong shade effect leads to low presence of bryophytes. The litter also formed separate layer and has cover about 90-95\%. From syntaxonomical point of view communities of this habitat belongs to alliance Filipendulion ulmariae Westhoff \& Den Held 1969, order Filipendulo ulmariae-Lotetalia uliginosi Passarge 1975 and class Molinio-Arrhenatheretea.

\section{Lowland hay meadows}

Abiotic characteristic: This habitat type has a fragmented distribution and only within the eastern part of the municipality. It is presented by 153 polygons and occupies a total area of $3.94 \mathrm{~km}^{2}$. The biggest areas are located in the vicinities of Malo Malovo, Vasilovtsi 
and Tsraklevtsi villages. Sometimes, this habitat type forms complexes with habitat 6410 Molinia meadows on calcareous, peaty or clayey-siltladen soils (Molinion caeruleae). Most often, the bedrock types are limestones, dolomitic limestones, dolomites and less shales, sandstones, siltstones and less often - boulders, pebbles and sands. The altitude spans across the range of $620-850 \mathrm{~m}$ a.s.1.

Vegetation structure: Species rich mesic grasslands with closed horizontal structure and total cover in the range $80-100 \%$. It represents secondary grassland vegetation, found at the areas of former forests. These grasslands are managed as hay meadows and pastures. The most common plant species are Arrhenatherum elatius (L.) J. \& C. Presl., Festuca pratensis Huds., F. rubra agg. L., Alopecurus pratensis L., Cynosurus cristatus L. , Poa pratensis L., Convolvulus arvensis L., Trisetum flavescens (L.) P. Beauv., Crepis biennis L., Vicia cracca L., Agrostis capillaris L., Holcus lanatus L., Anthoxanthum odoratum L., Lathyrus pratensis L., Plantago lanceolata L. This vegetation is classified within class Molinio-Arrhenatheretea Tüxen 1937, order Arrhenatheretalia elatioris Tüxen 1931, alliances Arrhenatherion elatioris Luquet 1926 and Cynosurion cristati Tüxen 1947. Five associations belonging to this habitat type are recognized on the territory of Dragoman Municipality. Three associations present alliance Arrhenatherion: the mesic ones Ranunculo repentis-Alopecuretum pratensis (Eggler 1933) Ellmauer in Mucina \& al. 1993

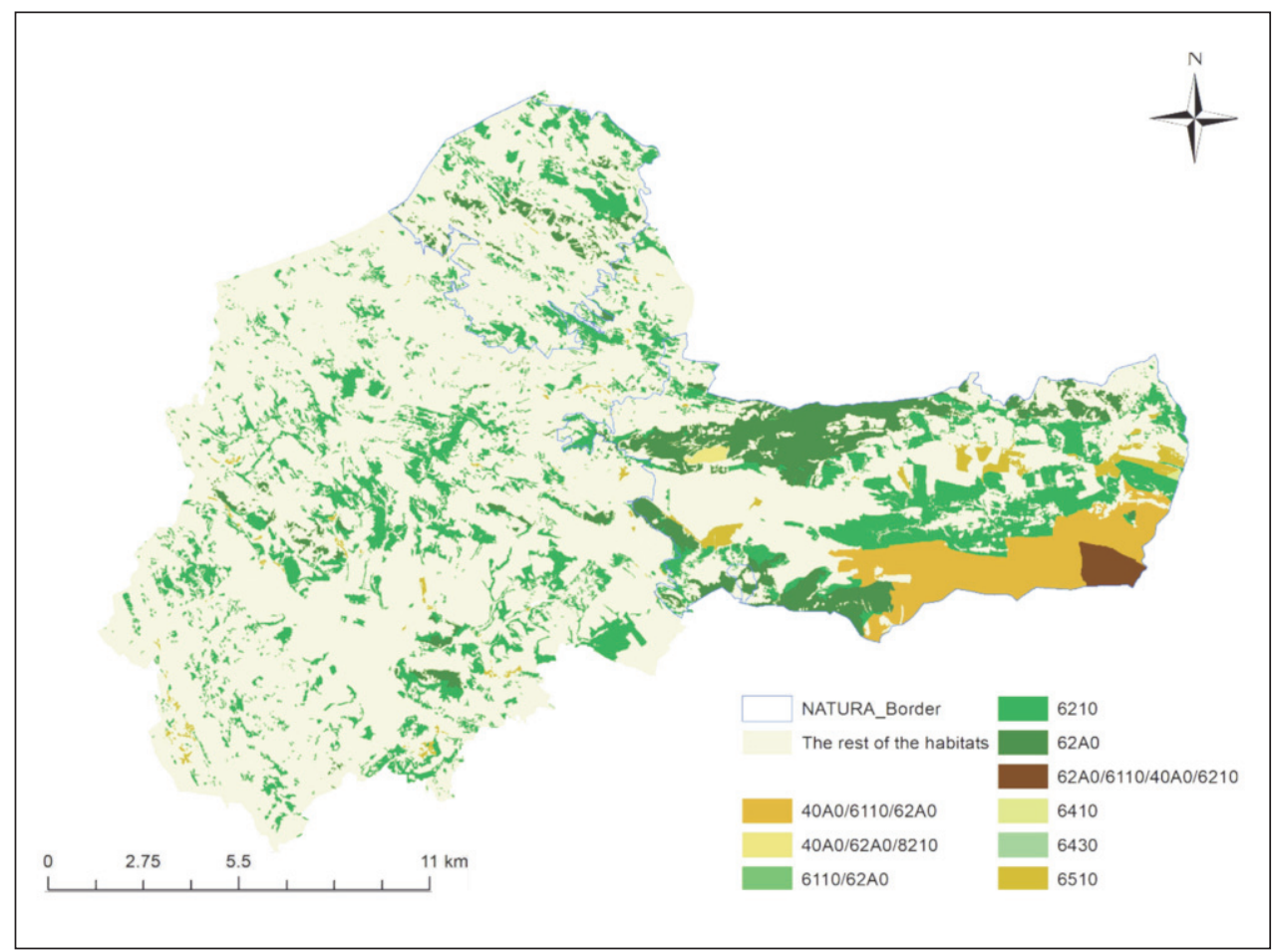

Fig. 2. Grassland habitats in Dragoman Municipality. 
and Pastinaco sativae-Arrhenatheretum elatioris Passarge 1964, and the xero-mesic Ranunculo bulbosi-Arrhenatheretum elatioris Ellmauer in Mucina \& al. 1993. Two associations from Cynosurion alliance are recorded: the mesic Bromo racemosi-Cynosuretum cristati Horvatić (1930) 1958 and the xero-mesic Festuco rubrae-Agrostetum capillaris Horvat 1951. All the associations listed were investigated by Velev \& al. (2011a, 2011b) in Bulgaria, including those in the studied region.

\section{Evaluation of habitat distribution, condition and threats}

This is the first municipality in Bulgaria where all habitat types, protected by Council Directive 92/43/EEC, were investigated and mapped, using the scale of 1:5000. In this paper we are focusing on the representation of grassland habitats, while the results for forest habitat types were prepared in other manuscript (Grigorov \& al. in review).

Six grassland habitats have a fragmented distribution, due to the physical characteristics of Dragoman Municipality and the prolonged anthropogenic influence. Habitat 62A0 is representing xerophyte grassland communities and can be discovered on carbonate rocks in the mountains of Mala Planina, Chepun and parts of Viskyar Mountain. Habitat 6110 has a local distribution only on eroded limestones in Mala Planina Mt. and Chepun Mt. Xero-mesophyte and xerophyte communities of habitat 6210 have an even distribution in the valleys and mountainous areas of the municipality. Mesophyte communities of habitat 6510 are found mainly on flat terrains or on slopes with up to $5-6^{\circ}$ inclination in the valley between Mala Planina Mt. and Chepun Mt. as well as in the higher parts of Viskyar Mt. Habitats 6430 and 6410 are locally distributed in areas with high water table. Following the official data habitat 6230 can be located only within 3 polygons. However, nowadays these areas are turned into agricultural areas.

The condition of the grassland habitats is different in the various parts of the municipality. Semi-natural grasslands and grasslands in the stage of formation, such as abandoned agricultural territories are typical for the area. The condition of those habitats that are close to the city of Dragoman and the ones that are falling within the boundaries of the NATURA 2000 sites has improved during last 7-8 years, because of the agricultural subsidies. Habitats 6210, $62 \mathrm{~A} 0$ and 6510 are known to have been abandoned for the period after the fall of the communism between 1989 and 2010. Extensive grazing was also observed, leading to an ecological change and an appearance of shrubs (10-15\%) and overgrazing plays a negative role by altering the ecological structure. Thanks to the subsidies these areas were cleared. A large proportion of the meadows are being mown each year. At the same time pastures are being grazed by sheep and cows. Moderate trampling occurs and cattle helps for the decomposition of nutrients, for example, yet when this processes happens in mid-summer, it leads to erosion and decline in the number of species. Unfortunately, habitats (mainly 6210 and 6510) in remote and depopulated areas, such as Viskyar Mt. and the border area between Bulgaria and Serbia are in a bad condition. In those areas non-grassland species such as Rosa sp. L., Crataegus monogyna Jacq., Prunus spinosa L., Rubus spp. L., Quercus frainetto Ten., Q. cerris L., Q. daleschampii (Ten.) A. Camus, Carpinus betulus L., C. orientalis Mill., Fagus sylvatica L. and Fraxinus ornus L. are becoming dominant. Conservation grazing may be adopted here in order to improve their condition. 
During the last 7-8 years some of the polygons that were a part of the NATURA 2000 network were turned into agricultural areas: $6210\left(1.78 \mathrm{~km}^{2}\right), 6230\left(0.21 \mathrm{~km}^{2}\right), 6430\left(0.14 \mathrm{~km}^{2}\right)$ and $6510\left(0.51 \mathrm{~km}^{2}\right)$. The abandonment of agricultural areas has led to ruderalization in the neighboring grassland polygons. Sites with a disposal of household waste and illegal landfills were found near some polygons of habitats 6210 and 6510. The invasion of Robinia pseudoacacia L. is occurring in polygons of habitat 6210 in parts of the slopes of Viskyar Mountain. During the last 10-15 years the exploitation of several quarries in the eastern parts of the municipality has led to the destruction of areas with habitats 6210 and 62A0.

\section{Acknowledgments}

This investigation was carried with the financial help of the national scientific programme "Young scientists and Postdoctoral students" for 2019, contract № 22-0078/ 22.04.2019 and the National Science Fund (Contract ДКОСТ 01/7/19.10.2018).

\section{References}

Apostolova, I., Petrova, C., Vassilev, P. 2001: Flora and vegetation of the Aldomirovsko marsh protected area. - Ann. Univ. Sofia "K1.Ohridski" Fac. Biol. Bot. 93(2): 115-132.

— \& Tsoneva, S. 2009: Salix rosmarinifolia L. - P. 70 in: Petrova, A. \& Vladimirov, V. (eds), Red List of Bulgarian vascular plants. - Phytol. Balcan. 15(1): 63-94.

— \& - 2015: Salix rosmarinifolia L. - in: Peev, D., Vladimirov, V., Petrova, A., Anchev, M., Temniskova, D., Denchev, Ts., Ganeva, A. \& Gussev, Ch. (eds), Red Data Book of the Republic of Bulgaria, 1. - Sofia.

Braun-Blanquet, J. 1965: Plant Sociology. The Study of Plant Communities. - New York \& London. Commission of the European Communities, 2013: Interpretation manual of European Union habitats-EUR 28. DG Environment Nature and Biodiversity. Brussels. Commission of the European Communities. -https://ec.europa.eu/environment/nature/legislation/habitatsdirective/docs/Int_Manual_EU28.pdf [Last accessed 2/3/2021]

Council Directive 92/43/EEC of 21 May 1992 on the conservation of natural habitats and of wild fauna and flora. - http://ec.europa.eu/environment/nature/legislation/habitatsdirective/ index_en.htm [Last accessed 2/3/2021]

Delipavlov D. \& Cheshmedzhiev I. (eds). 2003: Key to the plants of Bulgaria. - Plovdiv.

Dengler, J., Biurrun, I., Apostolova, I., Baumann, E., Becker, T., Berastegi, A., Boch, S., Cancellieri, L., Dembicz, I., Didukh, Y. P., Dolnik, C., Ermakov, N., Filibeck G., Garcia-Mijangos, I., Gusso del Galdo, G., Guarino, R., Janišová, M., Jaunatre, R., Jensen, K., Jeschke, M., Kącki, Z., Kozub, Ł., Kuzemko, A. A., Löbel, S., Pedashenko, H., Polyakova, M., Ruprecht, E., Szabó, A., Vassilev, K., Velev, N. \& Weiser, F. 2016: Scale-dependent plant diversity in Palaearctic grasslands: a comparative overview. - Bull. EDGG 31: 12-26.

Fahring, L. 2003: Effects of habitat fragmentation on biodiversity. - Ann. Rev. Ecol. Evol. Syst. 34(1): 487-515. https://doi/10.1146/annurev.ecolsys.34.011802.132419

Háyek, M., Hájková, P., Apostolova, I., Sopotlieva, D. \& Velev, N. 2006: Reports 49-52. - In: Vladimirov, V., Dane, F., Nikolic, T., Stefanovic, V. \& Tan, K. (eds), New floristic records in the Balkans: 2. - Phytol. Balcan. 12(2): 286-287.

Házi, J., Bartha, S., Szentes, S., Wichmann, B. \& Penksza, K. 2011: Seminatural grassland management by mowing of Calamagrostis epigejos in Hungary. - Pl. Biosyst. 145: 699-707. https://doi.org/10.1080/11263504.2011.601339 
Horvat, I., Glavač, V. \& Ellenberg, H. 1974: Vegetation Südosteuropas. - Stuttgard.

Information system for protected areas of the ecological network NATURA 2000 in Bulgaria. http://natura2000.moew.government.bg/ [Last accessed 3/3/2021]

Kavrakova, V., Dimova, D., Dimitrov, M., Tzonev, R., Belev, T. \& Rakovska, K. (eds.) 2009: Manual for Determination of Habitats with European Importance in Bulgaria. $2^{\circ}$ ed. -Sofia [in Bulgarian].

Knapp, R. 1979: Distribution of Grasses and Grasslands in Europe. - Pp. 111-123 in: Numata, M. (ed.) Ecology of Grasslands and Bamboolands in the World. - Jena.

McCune, B. \& Mefford, M. 1999: PC-ORD. Multivariate analysis of ecological data. Version 4. Gleneden Beach.

Meshinev, T., Apostolova, I., Petrova, A. \& Georgiev, V. 2009: Grassland in North-Eastern Bulgaria - tradition and changes. - Pp. 246-255 in: Veen, P., Jefferson, R., de Smidt, J. \& van der Straten, J. (eds), Grasslands in Europe of high nature value. - Zeist.

Mucina, L., Bültmann, H., Dierßen, K., Theurillat, J.-P., Raus, T., Čarni, A., Šumberová, K., Willner, W., Dengler, J., Gavilán García, R., Chytrý, M., Hájek, M., Di Pietro, R., Iakushenko, D., Pallas, J., Daniëls, F. J. A., Bergmeier, E., Santos Guerra, A., Ermakov, N., Valachovič, M., Schaminée, J. H. J., Lysenko, T., Didukh, Ya. P., Pignatti, S., Rodwell, J. S., Capelo, J., Weber, H. E., Solomeshch, A., Dimopoulos, P., Aguiar, C., Freitag, H., Hennekens, S. M. \& Tichý, L. 2016: Vegetation of Europe: Hierarchical floristic classification system of vascular plant, bryophyte, lichen, and algal communities. - Appl. Veg. Sci. 19: 3-264. https://doi/10.1111/avsc. 12257

Nikolov, S. 2010: Effects of land abandonment and changing habitat structure on avian assemblages in upland pastures of Bulgaria. - Bird Conserv. Intern. 20: 200-213.

Roleček, J., Čornej, I. I. \& Tokarjuk, A. I. 2014: Understanding the extreme species richness of semidry grasslands in east-central Europe: A comparative approach. -Preslia 86: 13-34.

Sopotlieva, D., Velev, N., Tsvetkova, N., Vassilev, V. \& Apostolova, I. 2018: Ecosystem condition assessment of semi-natural grasslands outside the Natura 2000 network in Bulgaria, using vegetation data. - Tuexenia 38: 385-404. https://doi.org/10.14471/2018.38.012.

Tichý, L. 2002: JUICE, software for vegetation classification. - J. Veg. Sci. 13: 451-453.

Turtureanu, P. D., Palpurina, S., Becker, T., Dolnik, C., Ruprecht, E., Sutcliffe, L. M. E., Szabó, A. \& Dengler, J. 2014: Scale- and taxon-dependent biodiversity patterns of dry grassland vegetation in Transylvania. - Agric. Ecosyst. Environ. 182: 15-24. https://doi.org/10.1007/s10531016-1093-y

Traykov, I. \& Tosheva, A. 2015: Primary productivity of restored wetland - Dragoman marsh, Bulgaria. - Intern. J. Res. Stud. Biosci. (IJRSB) 3(6): 61-66.

Tzonev, R., Dimitrov, M. \& Roussakova, V. 2009: Syntaxa according to Braun-Blanquet approach in Bulgaria. - Phytol. Balcan. 15(2): 209-233.

Vassilev, K. 2012: Grassland vegetation on limestone terrains western of Sofia. -Dissertation. Sofia.

-, Apostolova, I. \& Pedashenko, H. 2012: Festuco-Brometea in Western Bulgaria with an emphasis on Cirsio-Brachypodion pinnati. - Hacquetia 11: 227-248. https://doi.org/10.2478/v10028012-0011-4

-, Gecheva, G., Ilieva, T. 2019: Macrophyte-based Assessment of Ecological Status of Aldomirovsko and Dragomansko Marshes, Bulgaria. - Ecol. Balkan 11(1): 161-166.

—, Pedashenko, H., Nikolov, S. C., Apostolova, I. \& Dengler, J. 2011: Effect of land abandonment on the vegetation of upland semi-natural grasslands in the Western Balkan Mts., Bulgaria. Pl. Biosyst. 145: 654-665. http://doi/abs/10.1080/11263504.2011.601337

_, - , Velev, N. \& Apostolova, I. 2014: Grassland vegetation of Special Protection Area "Ponor". Acta Zool. Bulgar. 5 (suppl.): 61-73. 
-, - Alexandrova, A., Tashev, A., Ganeva, A. Gavrilova, A. Gradevska, A., Assenov, A. Vitkova, A., Grigorov, B., Gussev, Ch., Filipova, E., Aneva, I., Knollova, I., Nikolov, I., Georgiev, G., Tinchev, G., Pachedjieva, K., Koev, K., Lyubenova, M., Dimitrov, M., Apostolova-Stoyanova, N., Velev, N., Zhelev, P., Glogov, P., Natcheva, R., Tzonev, R., Boch, S., Hennekens, S., Georgiev, S., Stoyanov, S., Karakiev, T., Kalnikova, V., Shivarov, V., Roussakova, V. \& Vulchev, V. 2016: Balkan Vegetation Database: historical background, current status and future perspectives. - Phytocoenologia 46(1): 89-95. https://doi.org/10.1127/phyto/2016/0109

Velev, S. 2010: Climate of Bulgaria. -Sofia [in Bulgarian].

— \& Apostolova, I. 2008: Successional changes of Nardus stricta communities in the Central Balkan Range (Bulgaria). - Phytol. Balcan. 14(1): 75-84.

— \& Vassilev, K. 2014: Management regimes within syntaxa of semi-natural grasslands from West Bulgaria. - Hacquetia 13(1): 191-204. https://doi/full/10.1111/10.2478/hacq-2014-0003

-, Apostolova, I., Fajmonová, Z. 2011a: Cynosurus cristatus grasslands in West Bulgaria. - Phytol. Balcan. 17(2): 221-236.

—, - Rozbrojová, Z. 2011b: Alliance Arrhenatherion elatioris in West Bulgaria. - Phytol. Balcan. 17(1): $67-78$.

Wilson, J. B., Peet, R. K., Dengler, J. \& Pärtel, M. 2012: Plant species richness: the world records. - J. Vegetati. Sci. 23: 796-802. https://doi/full/10.1111/j.1654-1103.2012.01400.x

Addresses of the authors:

Borislav Grigorov ${ }^{*}$, Nikolay Velev², Assen Assenov ${ }^{1}$, Momchil Nazarov², Mladen Gramatikov $^{4}$, Beloslava Genova ${ }^{3}$, Kiril Vassilev²,

${ }^{1}$ Faculty of Geology and Geography, Sofia University "St. Kliment Ohridski”, Sofia, Bulgaria. E-mail: borislav.g.grigorov@gmail.com

${ }^{2}$ Institute of Biodiversity and Ecosystem Research, Bulgarian Academy of Sciences, Department of Plant and Fungal Diversity and Resources, Sofia, Bulgaria.

${ }^{3}$ Biological Faculty, University of Plovdiv "Paisii Hilendarski", Tzar Asen 24, 4000, Plovdiv, Bulgaria.

${ }^{4}$ FCG Povvik Ltd.,12 Mihail Tenev Street, 1784 Sofia, Bulgaria.

*corresponding author. 